\title{
Reducing aflatoxin toxicity of contaminted diet fed to guinea pigs by addition of Egyptian Tafla
}

\author{
Nowar, M.S.(1); El-Neshawy Saneya M. ${ }^{(2)}$;El-Meleigy Kh.M(3).and Abdel - Salam \\ A. $\mathbf{F}^{(3)}$. \\ (1)Dept of Anim. Prod. Fac. Agric. Zagazig University \\ (2) plant Pathology Research Institute. Agriculture Research Center. \\ (3) Regional Centre for Food and Feed Agriculture Research Centre
}

\begin{abstract}
Effect of Egyptian Tafla on reducing the toxicity of aflatoxin was examined by adding different levels of Tafla to an aflatoxin contaminated diet fed to 30 growing male guinea pigs (average $133 \mathrm{gm}$ ). The animals divided into 5 groups equal in number and average body weight. Five diets were prepared uncontaminated diet (control), contaminated diet with aflatoxins $B_{t}, B_{2}, G_{1}$ and $G_{2}$ mixture (equals to $420 \mathrm{ppb}$ aflatoxin $\mathrm{B}_{1}$ ), aflatoxins contaminated diet supplied with 1/2, 1 or $2 \%$ Tafla. Each of the 5 animal groups was fed with one diet only. The following measurement were recorded, daily feed intake, daily body weight gain, feed efficiency, aflatoxin intake (ppb).

On the $17^{\text {th }}$ day of feeding period, three animals from each group were slaughtered. Blood samples were taken individually for biochemical study. Internal organs of each animal (liver, lung, kidney, heart and spleen) were clinically examined, weighed and samples for histopthological studies were taken.

The obtained results revealed that comparing to the uncontaminated (control) diet, feeding aflatoxins $B_{1}, B_{2}, G_{1}$ and $G_{2}$ mixture (equal to $420 \mathrm{ppb}$ as $\mathrm{B}_{\mathrm{I}}$ ) contaminated diet caused. Reduce in each of live body weight, body gain, feed intake and feed efficiency. Decrease in absolute weights of internal organs (significant only with liver and spleen) and significant increase in its relative weights. Decrease in serum total protein, ablumin and globulin, meanwhile an increase in serum total lipids, total cholesterol, creatinine, urea $-\mathrm{N}$, uric acid and GOT, GPT and alkaline phosphatase activities. The differences were significant $(\mathrm{P}<0.05)$ except in serum albumin, and urea $-\mathrm{N}$.

Addition of $1 / 2, I$ and $2 \%$ Tafla to the aflatoxins diet caused, minimize the losses in body weight and increased daily feed intake and prolonged the survival period of tested animals. Minimize the changes in blood serum components. Where the significant $(\mathrm{P}<0.05)$ decrease in serum globulin, cholesterol, and GOT, GPT and alkaline phosphatase activities become insignificant. However the hazard effect of aflatoxins ingestion
\end{abstract}


was minimized by addition of Tafla (especially the $1 / 2 \%$ level). The differences in serum creatinine and uric acid still significant comparing to the control diet. Minimized the hazard effect on liver and kidney functions. The $1 / 2 \%$ level of Tafla was the highest efficient in detoxification of aflatoxins and reducing its toxicity.

\section{INTRODUCTION}

Acute aflatoxicosis causes hepatitis, hemorrhage, immune suppression, genetic damage (carcinogenicity, teratogenicity and mutagenicity) and death Growth impairment and lowering of reproductive performance are the most sensitive clinical signs of chronic aflatoxicosis. Scientific efforts were directed towards using physical, chemical and biological techniques for detoxification or inactivation of aflatoxins. Abdel hamid et al.,1986,1992a,b; Abdel hamid, 1993 and Abdel hamid and Mahomoud 1996/ These techniques have not been used on a commercial scale due to high costs, the need for special facilities, losses of important nutrients and the questionable safety of chemical degradation products of aflatoxins.

Many adsorbents as activated charcoal, bentinite, zeonite aluminosilicates and yeast cell wall were tested for binding of several mycotoxins both in vitro and in vivo the degree of adsorption in in vitro depends on the physical structure of the adsorbent, i.e. the total charge and distribution, the size of the pores and the accessible surface area. On the other hand, the properties of the adsorbate molecules (the mycotoxins) such as polarity, solubility, size, shape and in case of ionized compounds, their charge distruibution (Alexander et al., 2001).

Recent information suggest that clay minerals and aluminsilicates added to mycotoxin - contaminated diets reduce the bioavailability of toxins and their hazardous effects in some animal species (Philips et al., 1990; Harvey et al., 1993, Kubena et al., 1993; schell et al 1993 and Schiedeler, 1993). The major advantages of adsorbent include law cast, safety and easy addition to animal feed. Nowar, et al.(2002) added bentonite at different levels to the Af-diet and proved the bentonite dimished to toxic effects of aflatoxins on all parameters of rabbit growth performance. Abd El-Baki et al. (2002) and Abdel hamid et al.(2005) found that addition of Tafla to Af-diet improved the growth performance daily body weight gain, feed consumption and feed efficiency in comparison with Af-diet. Yet, Abdel hamid et al.(2002) showed that the adorbents (Antitox plus and Fix- a- tox) were less effective in reducing aflatoxin productivity in YES - media for 
Aspergilus flavus, being 62.5 and $47.5 \%$, respectively, but Tafla reduced the productivity of aflatoxin by $91.5 \%$ comparing with the controls

This study was carried out to investigation the effect of feeding aflatoxins $B$, , B2, G, G2 mixture (equals to $420 \mathrm{ppb} B$,) contaminated diet on growing male guinea pigs and the effect of adding different levels of Tafla to such contaminated diet on reducing aflatoxins toxicity.

\section{MATERIALS AND METHODS}

For producing aflatoxin the strain of Aspergillus flavus NRRL 3357 was grown in synthetic media, yeast extract - sucrose broth (YES) containing $2 \%$ yeast extract and $20 \%$ sucrose. The substrate was dispensed in conical flask. The flasks were then autoclaved for 15 minutes at $121 \mathrm{C}^{\circ}$, then coold and inoculated with spore suspension and incubated for 9 days at $25-29 C^{\circ}$. Aflatoxin concentrations determined using A.O.A.C (1984) and Shih and Marth (1969). The media was found to contain a mixture of aflatoxins $B_{1}, B_{2}, G$, and $G 2$.

Thirty growing male guinea pigs (average weight $133 \mathrm{gm}$ ) were randomly assigned to one of five dietary treatments (6 animals for each), uncontaminated diet (control), diet contaminated with $0.42 \mu \mathrm{g}$ aflatoxin $/ \mathrm{kg}$ diet and aflatoxin contaminated diet provided with one of three levels of natural Egyptian Tafla $1 / 2,1$ and $2 \%$. Tafla used in study contained (\%) : $50.05 \mathrm{SiO}_{2} ; 20.26 \mathrm{Al}_{3}$; $9.74 \mathrm{Fe}_{2} \mathrm{O}_{3} ; 2.02 \mathrm{CaO}, 1.95 \mathrm{MgO} ; 2.19 \mathrm{Na} 2 \mathrm{O}$; $1.05 \mathrm{~K}_{2} \mathrm{O}$ and 12.74 others.

On day 17 of feeding period, three animals from each group were slaughtered and internal organs of each one (liver, heart, lungs, spleen and kidneys) were removed from the body and subjected to the clinical and histopathological examination, according to Bancroft et al.,(1990)

At slaughter, blood sample from each animal was taken into dry glass tube and left to clot. Blood serum was separated by centrifugation at 3000 r.p.m. for 15 minutes. Serum was analyzed for total protein, albumin, total lipids, total cholesterol, glotamate-oxaloacetate transaminase (GOT), glotamate-pyruvate transaminase (GPT), urea $\mathrm{N}$, uric acid and creatinine. The biochemical determinations of blood serum parameters were performed colorimetrically by using commercial kits purchased from Egyptian - American Company for Laboratory Services, Egypt.

The data of all parameters were statistically analyzed as completely randomized design by using analysis of variance according to Snedecor and Cochran (1982). Significant differences among treatment 
means were statistically tested by using Duncan's New Multiple Rang Test (Duncan, 1955).

\section{Body weight:}

\section{RESULTS AND DISCUSSION}

Table (1) shows the body weight of guinea pigs fed diet contaminated with aflatoxins $B{ }_{1}, B,, G, \& G_{2}$ mixture (equals to $0.42 \mu \mathrm{g}$ aflatoxin $B_{1} / \mathrm{kg}$ diet) alone or with $1 / 2,1$ and $2 \%$ Egyptian Tafla. Body weight was the highest $(261.7 \mathrm{gm})$ in animals fed the control diet, the lowest $(127.5 \mathrm{gm})$ in those fed the aflatoxins diet alone (without Tafla), and intermediate in animals fed aflatoxin diet provided with Tafla.

\section{Survival period :}

Survival period (Tables 2) was the shortest (19 days) in animals fed aflatoxin diet alone, and it was 29, 25 and 22 days in animals fed aflatoxin diet supplied with $1 / 2,1$ and $2 \%$ Tafla, respectively.

\section{Body gain :}

Table (2) shows that animals fed aflatoxin - diet alone or with $2 \%$ Tafla lost some of their initial body weight being 9.2 and $3.3 \mathrm{gm}$, respectively. Meanwhile animals fed aflatoxin diet supplied with $1 / 2$ and $1 \%$ Tafla gained 16.7 and $5 \mathrm{gm}$, respectively.

\section{Feed intake :}

Average daily feed intake (Table 2$)$ was the highest $(26.7 \mathrm{gm})$ in the control group, the lowest $(11.39 \mathrm{gm})$ in group received aflatoxins diet alone and ranged from 13.10 to $15.03 \mathrm{gm}$ in groups received Tafla with the aflatoxin diet.

\section{Aflatoxin intake :}

Table (2) shows that total aflatoxin intake in group fed aflatoxin diet alone was $90.3 \mathrm{ppb} / \mathrm{animal}$, and the survival period was 19 days. Aflatoxins intake increased to $183.1,137.8$ and $120.7 \mathrm{ppb} /$ animals and the survival period prolonged to 29, 25 and 22 days as a result of adding 1/2, 1 and $2 \%$ Tafla to this aflatoxins diet, in respective orders. These results might be, indicated that addition of Tafla to the aflatoxins diet, however, increased feed intake, and consequently increased aflatoxins intake, the survival periods were prolonged. This results cleared the role of Tafla in detoxification of aflatoxins. The level $1 / 2$ Tafla was the highest efficient level in binding aflatoxins and reducing their toxicity.

This results agreed with those of Nowar et al., 2001; Shehata 2001 and Abd El-Baki et al (2002) on rabbit, Shehata et al., (2003) and Abdel hamid et al (2004) on Tilapia fish, Schell et al (1993) and Harvety et al (1993) on growing pigs and Abdel hamid et al (2005) on rats.

\section{Internal organs :}


Animals fed aflatoxins diet alone or with Tafla were lower in absolute weight of internal organs (liver lungs, kidneys, heart and spleen) than the control group (Table 3). The relative weight of internal organs showed an opposite trend being significantly higher in animal fed aflatoxin diet alone or with Tafla than those fed the control diet. These results agreed with those of Nowar et al, 1996 and 2000.

\section{Blood serum analysis :}

Table (4) shows blood serum components of guinea pigs fed aflatoxins $B_{1}, B_{2}, G_{1} \& G_{2}$ mixture (equals to 0.42 ppm as $B_{1}$ ) diet alone or with different level of Tafla. Comparing to the control diet, feeding aflatoxin diet decreased serum total protein, albumin and globulin and increased serum total lipids, total cholesterol, creatinine, urea - N, uric acid and GOT, GPT, alkaline phosphatase and acid phosphatase activities. The differences were significant .

Addition of Tafla especially the $1 / 2 \%$ level to the aflatoxins diets minimized the changes in serum components. However, the differences than the control animals were still significant $(P<0.05)$ in serum total lipids, creatinine, uric acid and alkaline and acid phosphatase activities.

The significant differences in serum globulin, total cholesterol, GOT and GPT activities resulted from aflatoxins ingestion become insignificant as a result of adding Tafla to the aflatoxins contaminated diet.

\section{Liver function:}

Feeding aflatoxins diet alone or with Tafla as prementioned insignificantly decreased serum total protein and globulin and significantly increased GOT, GPT and alkaline phosphatase activities than the corresponding figures of animals fed the control diet. These results indicated that liver function affected by ingestion of aflatoxins alone or with Tafla. But, this hazard effect was minimized by ingestion of Tafla especially the $1 / 2 \%$ level, where there were no significant differences between the control animals and those fed aflatoxins diet supplied with $1 / 2 \%$ Tafla in the values of each of serum total protein, albumin, globulin, and GOT and GPT activities.

\section{Kidney fuction :}

As previously mentioned (Table 4) serum creatinine, urea $-\mathrm{N}$ and uric acid of animals fed aflatoxins diet alone or with Tafla $1 / 2 \%$ were higher than those of the control animals. The difference were significant $(P<0.05)$ except in serum urea - N. This results indicated that kidney function affected by ingestion of aflatoxins alone or with tafla. But the hazard effect was minimized by ingestion of Tafla especially the \% level, however the differences in serum creatinine and uric acid than the control animals were still significant. 
The obtained results confirmed that addition of Tafla at a rate of $1 / 2 \%$ to aflatoxins $\left(0.42 \mathrm{ppm}\right.$ as $\left.\mathrm{B}_{1}\right)$ diet was functioned in binding aflatoxins and reducing its toxicity. These results agreed with those of Abdel hamid et al. (2005) on rats, Nowar et al (1996) and Abdel Baki et al (2002) on growing male NZW rabbits, and EI - Zahar et al. (1996) on mature rabbits, and schell et al (1993) and Harvey et al (1993) on growing pigs.

\section{Pathological examination:}

\section{I-The kidneys:}

Grossly, the kidneys are slightly enlarged, grey in colour and slightly firm in consistency. Microscopically the kidneys revealed that their glomerul; shirnk with small intrarenal empty spaces The renal tubules are suffered from various degenerative changes while appeared as cloudy swelling and vacuolation in other renal tubules. The renal blood vessels are also congested.

\section{2- The liver:}

Grossly, the liver appeared enlarged and congested. The cut surface appeared also redish in color and freely blood oozed. Microscopically the hepatic blood vessels are severely enlarged. Some hepatic cells suffered from variable degenerative changes and other .hepatic cells are reversed.

The histopathological aleration observed in sections of kidney and livers from guinea pigs fed on Af-diets are in agreement with those found by Nowar et al.,2001, Soliman et al 2001 Vinita et al 2003 and Abdelhamid et al 2004a on different animal.

\section{CONCLUSION AND PRACTICAL APPLICATION}

It could be concluded from the obtained results that feeding growing male guinea pigs on aflatoxins $B_{1}, B, G_{1} \& G_{2}$ mixutre (equals to 420 $\mathrm{ppb}$ ) diet, decreased each of body gain, feed intake, feed efficiency, survival period, internal organs, and liver and kidney functions. Supplying such diet with Egyptian Tafla (especially at a rate of $1 / 2 \%$ ) minimized the deleterious effect of

aflatoxins, which indicate the role of Tafla in binding aflatoxins and consequently- reducing their toxicity. Therefore, it could be recommended the addition of Tafla at a rate of $1 / 2 \%$ to the aflatoxins (420 ppb as $\mathrm{B}_{1}$ ) diet, can substantially provide a simple, effective, cheap and safe practical technique for prevention or reduction of aflatoxicosis in growing guinea pigs.

REFERENCES

Abd El Baki , S.M.; Nowar, M.S.; Hassona, E.A.; Bassuny , S.M. and 
Shehata (2002). Clay in animal nutrition: 10- Detoxification of aflatoxin B1 by Tafla in rabbit feeds. Pro. $3^{\text {rd }}$ scientific conf. Rabbit production in Hot Climates 8-11 October PP : 557-567

Abdelhamid , A.M. and Mahmoud, K.I. (1996). Elimination or adsorption of aflatoxin forom poultry feed stuffs. Proc. Conf. food borne contamination and Egyptian's Healthy 26-27 Nov. PP: 61-69.

Abdelhamid , A.M.; Dorra, T.M. and Arief, H.A. (1992a). Attempts to detoxicate aflatoxin - contaminated d-broiler diet. $\mathrm{Vi}^{\text {th }}$ International Symposium World Association of Veterinary Laboratory Diagnosticians June, Lyon, France.

Abdelhamid, A.M. (1993). Decontamination of aflatoxins contaminated foods by some physical means. J. Egypt. Ger. Soc. 2001, 12(A) : $191-208$.

Abdelhamid, A.M.; Ahmed, A.M. and El-Meleigy Kh.M.(2002). Detoxification of aflatoxins contaminated diet by some physical and chemical means. J. Agric. Sci. Mansoura univ. 27: 8213-8224.

Abdelhamid, A.M.; Ahmed, A.M. and El-Meleigy Kh.M.(2004a). An attempt to alleviate the histological alteration of some internal organs of rats fed on aflatoxin contaminated diets J.Agric. Sci., Mansoura unive., 29: 2355-2370.

Abdelhamid, A.M.; El Meleigy, Kh.M. and Amal M. Ahmed (2005). Possibility of alleviating food borne aflatoxicosis Effects on performance and biochemistry of male albino white rats. J. Agric. Sci. Mansoura univ., 30(2) : 833-849.

Abdelhamid, A.M.; El-Shawaf , I; El - Ayoty, S.A.; Ali M.M. and (1986). Effected of low levels of dietary aflatoxins on Baladi rabbits. Fourth International symposium of veterinary Laboratory Diagnostication , June 2-6 Amesterdam, PP : 151-154

Abdelhamid, A.M.; Mansy, S.S.; Dorra, T.M. and Sallam , A.E. (1992b). Effect of dietary energy, protein and amino acids on broiless fed aflatoxin B1 contaminated diets. Proc. $3^{\text {rd }}$ World Cong. Food borne Infections and Intoxications, Berlin, 16-1 June, PP : 674 -677.

Abdelhamid,A.M.; Mehrim, A.l. and Khalil, F.F. (2004-b). Detoxification of aflatoxin -(contaminated diet of Tilapia fish using dietery supplementation with egg shell, betafin, clay or silica , J. Agric. Sci., Mansoura univ. 24: 3463-3174.

Alexander, H.; Stefan, F. ; Othmar, K. and Hans , D. (2001). Mycotoxin detoxification of animal feed by different adsorbents. Toxicology letters 122 : 197- 188.

Association of Official Analytic Chemistry (AOAC) (1984): Ed. William Horzitw, 13 ed. Publisher, Washington.S.A. 
Bancroft, J.D., Sterens A. and Turner, D.R. (1990): Theory and Practice of histological technique. $3^{\prime \prime}$., Ed., Churchill; Livingston, Edingbargh, London Melbourne and New York.

Duncan, D.B. (1955): Multiple Range and Multiple F test. Biometrics, 11 $: 1-42$.

El-Zahar, Hoda, Tharwat, E.E., Abd El-Aal, W., El - Ashry, M.A., Saad, M.M. and Amin, S.O. (1996): Rabbits and aflatoxins. 2Repreductive performance of mature New Zealand white rabbit bucks treated orally with aflatoxins. Egyptian Journal of Rabbit science, 6 (1): $67-78$.

Harvey, R.B., Kubena, L.F., Elissalde, M.H. and Phillips, T.D. (1993): Efficacy of zeolite ore compounds on the toxicity of aflatoxin to growing broiler chichens. Avian Diseases, $37: 67$ - 73.

Kubena, L.F., Harvey, R.B., Huff, W.E., Elissalde, M.H., Yersin, A.G., Nowar, M.S., El-Gaafary, M.N., Tawfeek, M.I., and Ibrahim, Zenate A. (2000): Aflatoxicosis in rabbits. 3. Effectiveness of Egyptian raw bentonite in prevention or diminution the detrimental effects of aflatoxins-naturally contaminated diet on semen characteristics and reproductive performance. (Proceeding 22 Mycotoxin-Workshop as a special issue of the Journal "Mycotoxin Research", Germany.

Nowar, M.S., Hassona, E.M. and Abd El-Rahim, M.I. (1996): Aflatoxicosis in rabbits : 2-Prevention of aflatoxicosis in growing rabbits by addition of tafla to aflatoxin - naturally contaminated diet. Proceeding of Conference on Food-Borne Contamination and Egyptian's Health. University of Mansoura, Egypt. pp 97-111.

Nowar, M.S.; Abd El-Rahim, M.I.; Tawfeek , M.I. and Ibrahim Zenate A. (2001). Effect of various levels of Egyptian raw bentonite on detoxification of rabbits diet naturally. Contaminated with aflatoxins Proc. $8^{\text {th }}$ conf. Animal Nutrients 23-26 October. Sharm El - Sheikh , Egypt. Egyptian J. Nutrition and feeds, $4: 845-860$.

Phillips, T.D. and Rotinghaus, G.E. (1993): Efficacy of a hydrated sodium calcium aluminosilicate to reduce the toxicity of aflatoxin and diacetoxyscirpenol. Poultry Science, $72: 51-59$.

Phillips, T.D., Clement, B.A., Kubena, L.E. and Harvey, R.B. (1990): Detection and detoxicicantion of aflatoxins: Prevention of aflatoxicosis and aflatoxin residues with hydratd sodium calcium aluminosilicate. Journal of Veterinary and Human Toxiocology, 32 (Suppl) : 15.

Pier, A. C. (1992): Major biological consequences of aflatoxicosis in animal production. Journal of Animal Science, 70 : 3964 - 3967.

Scheideler, S.E. (1993) : Effects of various types of aluminosilicates and aflatoxin $B_{1}$ on aflatoxin toxicity, chick performance and mineral status. 
Poultry Science, $72: 282-288$.

Schell, T.C., Lindemann, M.D. Kernegay, E.T. and Blodgett, D.J. (1993) : Effects of feeding aflatoxin - contaminated diets with and without clay to wean ling and growing pigs on performance, liver function and mineral metablism. Journal of Animal Science, $71: 1209-1218$.

Sheata, S.A.; Mohamed, M.S. and Mohamed, G.A. (2003). Reducing the toxicity of aflatoxin B1 by different adsorbents in fish. J. Agric Sci. Mansoura univ. 28 (10) 7157-7167.

Shehata, S.A. (2001). Detoxification of mycotoxin contaminated animal feed stuffs. Ph.D. Thesis. Zagazig univ. fac. Agric.

Shih, C.N. and Marth, E.H. (1969): Improved procedures for measurement of aflatoxins with thin layer chromatography and fluorometory. J. Milk. Food Technol., $32: 213-217$.

Soliman, K.M.; El-Faramawy, A.A; Zakaria, S.M. and Mekkawy, S.H. (2001). Monitoring the preventive effect of hydrogen peroxide and gamma - radiation of aflatoxicosis in growing rabbits the effect of cooking on aflatoxin residues. Journal of Agricultural and food chemistry, 49 (7) : 3291-3295.

Vinita, R.; Prosacl, L.N.; Sinha , B.K. and Rani, V. (2003). Pathological and histochemical changes in liver and kidney in experimental aflatoxicosis in rabbits. Indian Journal of veterinary Pathology, $27: 1,57$. 